\title{
MUZYKA ALTERNATYWNA JAKO PUNKT WYJŚCIA DO DIALOGU MIĘDZYKULTUROWEGO
}

\begin{abstract}
Słowa kluczowe: muzyka alternatywna, piosenka w nauczaniu języka polskiego jako obcego i kultury polskiej jako obcej, treści lingwakulturowe w piosenkach

Streszczenie. Artykuł stanowi refleksję na temat włączania piosenek z kręgu polskiej muzyki alternatywnej do dydaktyki nauczania języka i kultury polskiej. Autor dowodzi, że liczne teksty z tej grupy po pierwsze, zawierają bogaty materiał o charakterze lingwakulturowym, a po drugie mają dyskursywny stosunek do wzorców kulturowych. Obie cechy sprawiają, że muzyka alternatywna stanowić może wartościowe źródło poszukiwania tekstów stymulujących do zestawiania, porównywania i poszukiwania porozumienia w ramach różnych kultur, jak też inicjowania dyskusji na temat polskiej kultury. Podstawę teoretycznych rozważań stanowi dyskusja o miejscu kultury popularnej w glottodydaktyce polonistycznej, tocząca się w ostatnich dwudziestu latach. W ostatniej części autor przywołuje przykłady utworów wykorzystywanych we własnej praktyce lektorskiej, badając, na ile dokonany przez niego subiektywny wybór mieści się w zakresie koncepcji programowych nauczania kultury polskiej. Prezentowane przykłady rekomendowane są do pracy ze studentami na poziomie średnim i wyższym, począwszy od B1.
\end{abstract}

\section{MUZYKA ALTERNATYWNA - WPROWADZENIE}

Celem artykułu jest podjęcie refleksji nad włączeniem piosenek z kręgu muzyki alternatywnej do procesu nauczania języka polskiego i kultury polskiej. Ponieważ niewątpliwie najbardziej interesuje nas warstwa tekstowa, być może bardziej adekwatne byłoby określenie: „piosenka alternatywna”, jednak nie chciałbym proponować takiego terminu ze względu na to, że z punktu widzenia dyskusji na temat muzyki, nie jest on naturalny. Muzykę alternatywną rozumiem jako muzykę zainicjowaną poza największymi koncernami wydawniczy-

*tomasz.wegner@uw.edu.pl, Uniwersytet Warszawski, Wydział Polonistyki, Centrum Języka Polskiego i Kultury Polskiej dla Cudzoziemców „Polonicum”, ul. Krakowskie Przedmieście 32, 00-927 Warszawa. 
mi i funkcjonującą (zwykle) poza najpopularniejszymi mediami. Rozumiem, że taka próba uchwycenia tego zjawiska może być niedoskonała. Np. coś może być „alternatywne” w swojej genezie, ale jednocześnie komercyjne i mimo etykiety „alternatywna”, może po prostu z powodzeniem funkcjonować na zasadach komercyjnych. Niejednoznaczne rozumienie tego pojęcia cechuje także literaturę specjalistyczną, czego przykładem może być sposób ujęcia zjawiska w raporcie, opracowanym przez Instytut Muzyki i Tańca:

W dzisiejszym polskojęzycznym dyskursie o muzyce rozmaitych stylów i «między-stylów», wobec chaosu terminologicznego związanego z przewartościowaniami w hierarchii sztuki, termin ten jest używany jako swoiste słowo-klucz w rozmaitych kontekstach. (...) nawiązując do słownikowego sensu wyrazu «alternatywny», rozumie się przezeń twórczość, która stanowić może kontrpropozycję wobec treści klasyfikowanych jako mainstream, aczkolwiek funkcjonuje w pokrewnym obszarze stylistycznym i charakteryzują ją wspólne inspiracje i podobne cele artystyczne.

(Raport o stanie..., 2011, s. 102)

Zwykle w potocznej czy medialnej dyskusji okołomuzycznej w przypadku etykietowania twórczości muzycznej jako „alternatywna” nie określa się, wobec czego dana twórczość miałaby stanowić alternatywę. Dlatego dla precyzji przywołuję krótkie definicje terminu ,alternatywny”: 1. dający możność wyboru między dwiema możliwościami, 2. inny, przeciwstawiający się temu, co tradycyjne i oficjalnie uznane (www.sjp.pwn.pl [04.05.2020]).

Jeśli coś jest alternatywne, musi stawiać się w kontrze do czegoś. Odnosząc to do polskich fenomenów związanych z muzyką, wyrazistym przykładem byłby np. yass ${ }^{1}$ - dynamiczny ruch młodych wówczas artystów, wśród których były postaci tak różne, obecnie znane z zaangażowania $\mathrm{w}$ autorskie projekty muzyczne, jak np. Leszek Możdżer, Tymon Tymański czy Mikołaj Trzaska. Yass to alternatywny pomysł na muzykę jazzową, jaki zaproponowali muzycy, którzy w latach 90. zapragnęli grać jazz niosący emocje i poszukujący nowych środków wyrazu, a nie tylko doskonały warsztatowo, powielający schematy i co najwyżej poszukujący rozwoju w elektronicznych brzmieniach, coraz łatwiej dostępnych w lokalnych studiach nagrań i domowych komputerach. Przedstawiciele sceny yassowej programowo zdefiniowali wobec czego proponują alternatywę. Jednak muzyka etykietowana jako alternatywna wcale nie musi charakteryzować się innym brzmieniem niż tzw. mainstream. Wówczas, bez znajomości kontekstu, możemy nawet nie być świadomi ,alternatywności” danego artysty.

${ }^{1}$ Dla zapoznania się z tym fenomenem lub przypomnienia go można posłużyć się liczną literaturą. Np. Rerak 2013, magazyn „Czas Kultury” 1/2001-w całości poświęcony temu zagadnieniu. Warty uwagi jest też film Miłość, 2013, reż. Filip Dzierżawski. 


\subsection{MUZYKA ALTERNATYWNA A KULTURA POPULARNA}

Muzyka alternatywna powstaje $\mathrm{w}$ wyniku potrzeby przełamania monotonii powielanych przez mainstream wzorców, wobec dominacji pewnych gatunków, wobec sposobów dystrybucji nagrań. Może także sprzeciwiać się nie wzorcom estetycznym, a normom społecznym. O ile część twórców wręcz programowo może dążyć do pozostania w niszy, to jednak liczni artyści tworzą z zamiarem przesunięcia granic kultury popularnej. Muzyka alternatywna powstaje jako forma dyskursywna wobec dominującej kultury popularnej, ale funkcjonuje w jej kontekście. Co więcej, patrząc na tę sprawę pod kątem estetyki, należy przypomnieć, że muzyczna alternatywa często czerpie z tych samych wzorców co tzw. mainstream. W niniejszych rozważaniach nie chodzi o wywrotową kontrkulturę, mającą zatrząść w posadach przyjętym systemem wartości i obowiązującą estetyką (chociaż i ona może pełnić niezwykle istotną rolę w dydaktyce, np. z powodzeniem można tego typu zjawiska ma świecie i ich lokalne rozprzestrzenianie się porównywać, a uczący się mogą je nawzajem poznawać i prezentować). Koncentruję się na piosenkach, które dzięki świeżości formy czy inteligentnej obserwacji mogą skupić na sobie uwagę odbiorcy poszukującego nowości. Nawet jeśli zaproponowane uczącym się piosenki nie są (jeszcze?) popularne na szerszą skalę, moim zdaniem tego typu twórczość już jest elementem kultury popularnej i jako taką proponuję ją rozpatrywać. Chciałbym jednak zastrzec, że wykorzystując na zajęciach teksty mniej znane, powinniśmy pamiętać o proporcjach (tego co znane do tego co mniej popularne). Warto też pamiętać, że pracując z tekstami kultury popularnej, dobrze jest wypracować metody opisywania skali ich popularności wśród Polaków. Ważne bowiem, żeby uczący się potrafili umieścić dane zjawisko w kontekście kultury polskiej, a więc wiedzieli, czy dany artysta jest rozpoznawany przez wszystkich Polaków, przez większość studentów czy też jego popularność ma charakter lokalny lub środowiskowy.

\subsection{MUZYKA ALTERNATYWNA, LOKALNOŚĆ I GLOBALNOŚĆ}

Dzięki temu, że już od lat 90. na polu rodzimej glottodydaktyki toczy się ożywiona dyskusja o potrzebie i o sposobach włączania kultury popularnej do nauczania, dziś wydaje się oczywiste, że tego typu materiały nie tylko niosą korzyść dla procesu dydaktycznego, ale ich włączenie staje się wręcz koniecznością. Jak stwierdza Kołak-Danyi (2019, s. 133): „Dziś, z powodu powszechnej globalizacji, migracji, zjawiska homogenizacji kultury, wzajemnej zależności czynników globalnych i lokalnych oraz wzrostu znaczenia kultur lokalnych, równie istotna dla 
zrozumienia rzeczywistości i specyfiki danego kraju jest kultura życia codziennego oraz kultura popularna". Wśród badaczy można znaleźć stwierdzenia jeszcze mocniejsze: „Aby przetrwać, system edukacyjny musi odnieść się do codziennej rzeczywistości. Przygotowanie do życia we współczesnych warunkach wymaga od edukacji włączenia w jej nurt również kultury popularnej” (Kajak 2020, s. 73).

$\mathrm{W}$ przeciwieństwie do kultury o ugruntowanej pozycji, z dostępem do sprawdzonych kanałów dystrybucji, muzyka alternatywna nieustannie musi aktywnie komunikować swoją obecność i zabiegać o swoje miejsce. Nie jest to więc w żadnym wypadku, ,świąteczna witryna sklepowa z narodowymi produktami, w najlepszym gatunku i wyborze" (Garncarek 2012, s. 11), ale realny dyskurs z rzeczywistością. Garncarek podkreśla dynamikę, towarzyszącą zjawiskom z kręgu kultury popularnej:

(...) kultura nie jest niczym stałym i dlatego tak niebywale trudno ją zinwentaryzować. Język ma korpusy i poziomy kompetencyjne. Kultura ma jedynie przestrzeń. Daje się dzielić na poszczególne obszary i obrazy, ale to - jak się zdaje - jedyny ład dający się tutaj wprowadzić. Kultura popularna jest jeszcze bardziej niesforna. Wymyka się narodowej kontroli, i to wymyka w dwóch kierunkach. Raz zmierza do powszechności, globalizacji i internacjonalizacji. Raz podąża w stronę niszy, prowincji, zaścianka, lokalności.

(Garncarek 2012, s. 12)

Te dwa kierunki „wymykania się” szeroko pojętej kultury popularnej (a więc dotyczy to także muzyki alternatywnej) - od globalizacji do lokalności - przywołane przez Piotra Garncarka we wstępie monografii Kultura popularna w nauczaniu języka polskiego jako obcego dają ogromną szansę glottodydaktyce kulturowej na spotkanie pośród kulturowej różnorodności, a warto zauważyć, że w sposób szczególnie interesujący te bieguny mogą uwypuklać się w alternatywnych, czyli będących dopiero na etapie formowania się zjawiskach. Mimo że kształt kultury lokalnej często wynika z globalnych inspiracji, to jednak zwykle nie jest to bezrefleksyjna kopia prekursorów, ale żywa, twórcza adaptacja. Potwierdzają to spostrzeżenia M. Pęczaka, poczynione na podstawie analizy języka piosenki rockowej ze szczególnego dla polskiego rocka okresu lat osiemdziesiątych, charakteryzującego się powiązaniem tekstów z napiętą sytuacją polityczną. Refleksje Pęczaka dotyczą muzyków takich jak Dezerter, Varieté czy Tomasz Lipiński. Badacz zaznacza, że twórców tych cechuje „bycie obok” lub lokalizuje ich w ,szarej strefie kultury”:

Od 1982 r. język polskiej piosenki rockowej ulegał szybkiej krystalizacji. Stał się bliski językowi codziennemu młodzieży. W większości odszedł od górnolotnych poetyckich metafor, żywcem wziętych z poezji romantycznej, od ogłaszania ogólnikowych prawd i nie dotyczącej nikogo krytyki. Zaczął się często posługiwać gwarą, szybką obrazową zbitką pojęciową, obserwacją życia potocznego, czasem dosadnymi określeniami. (...) obok przejmowania całościowego wzoru na przykład melodyki określonego nurtu muzycznego, rozwiązań harmonicznych, razem z najbardziej charakterystycznymi motywami ideologicznymi werbalnego przekazu, rodzimy wykonawca starał się włączyć swój 
produkt w kontekst bliskiej mu codzienności. (...) (w Anglii mogła to być kolejka po zasiłek dla bezrobotnych, w Polsce - uwikłania polityczne).

(Pęczak 2018, s. 53-54)

Artysta koduje znaczenia, odbiorca - dekoduje, a w tym procesie kontekstem dla odbiorcy, będącego uczącym się języka, jest jego własne doświadczenie kulturowe. Być może jest to założenie idealistyczne i nie dotyczy wszystkich spośród naszych studentów czy słuchaczy, ale zakładam, że osobie, która poznaje język polski, zależy, żeby dekodować znaczenia zawarte w tekstach polskiej kultury. Słuchając nowej muzyki, odbiorca odwołuje się do swoich dotychczasowych doświadczeń, w polskich piosenkach identyfikuje „melodykę określonego nurtu muzycznego, rozwiązań harmonicznych, razem z najbardziej charakterystycznymi motywami ideologicznymi werbalnego przekazu" (Pęczak 2018, s. 54) dzięki czemu wchodzi w tekst kultury poprzez to, co rozpoznane, a jednocześnie ma szansę zmierzyć się z tym, co nowe i specyficznie polskie. I tak, odwołując się do przywołanych twórców punkowych, moglibyśmy powiedzieć, że w tej konkretnej sytuacji:

- globalnym wyróżnikiem gatunku byłby protest wpisany w tego typu twórczość,

- lokalny, specyficzny dla danej rzeczywistości były adresat tego protestu.

\section{WSPÓLNOTA KULTUROWA JAKO CECHA GENERACYJNA (I KONSEKWENCJE TEGO FAKTU DLA SŁUCHANIA MUZYKI)}

Badacze nowoczesnej pedagogiki zwracają uwagę na fakt, że młodzi ludzie, mimo że pochodzą z różnych kultur, mają ze sobą wiele wspólnego. Oczywiście, istotny wpływ na taki stan rzeczy ma ich udział w globalnej kulturze popularnej:

Pojęcie globalnego nastolatka odwołuje się do badań, które wskazują, że wielkomiejską młodzież klasy średniej cechuje - niezależnie od kraju i kontynentu - podobna tożsamość i podobny styl życia. Nastolatek z tej klasy żyjący w Paryżu, Warszawie czy nawet Pekinie jest bardziej podobny do swojego rówieśnika z Sydney czy Limy z tej samej klasy niż do swojego rówieśnika żyjącego w jego własnym kraju w rodzinie chłopskiej lub robotniczej. Mało tego, powstanie światowej kultury młodzieżowej powoduje, iż nastolatki całego globu, włączając w to kraje Trzeciego Świata - są znacząco bardziej wzajemnie do siebie podobne niż do pokolenia swoich rodziców.

(Melosik 2014, s. 85)

Powyższa charakterystyka $\mathrm{w}$ dużym stopniu pokrywa się $\mathrm{z}$ lektorskimi doświadczeniami (mimo że dotyczy osób kilka lat młodszych niż studenci uniwersyteccy, z którymi autor niniejszego artykułu najczęściej spotyka się na 
swoich lektoratach). Jak dobierać odpowiednie treści dla takich osób? Wspólnota wzorców i doświadczeń estetycznych niesie ryzyko uśpienia ciekawości. „Skoro pop, niezależnie od własnej woli, słyszymy wszędzie, staje się on częścią cywilizacyjnego otoczenia" - stwierdza Rafał Księżyk (2018, s. 13), dziennikarz muzyczny i autor ważnych dla opisu polskich fenomenów kulturowych książek biograficznych. Czy ów pop, część otoczenia, towarzyszący naszemu życiu codziennemu, nie jest zbyt jednorodny, żeby odbiorca zdobył się na wysiłek przeniknięcia przez sferę dźwięków do warstwy tekstowej? To kwestia subiektywna, ale problem wymaga rozważenia. „Pedagogika kultury popularnej zakłada istnienie «ważnej metodologicznej możliwości» - bycia zdziwionym" - pisze dalej Melosik (2014, s. 85), sugerując, jak warto z owym „globalnym nastolatkiem” pracować.

Ponieważ powyższe spostrzeżenie można odnieść zarówno do nauczyciela, jak i uczącego się, warto, żeby lektor sam także próbował na nowo odkrywać i redefiniować swój stosunek do kultury. Może w tym pomóc właśnie sięganie od czasu do czasu po muzykę alternatywną. Może ona stworzyć warunki do wyzwolenia w sobie postawy odkrywcy (por. Zarzycka 2004), a stąd już krok do autentycznego dialogu międzykulturowego. „W trakcie takiej rozmowy można tworzyć (za pomocą strategii krytycznego myślenia) przestrzenie wyjścia poza dominujące (i często narzucone) interpretacje i reprezentacje świata. Można konstruować alternatywne systemy znaczeń" (Melosik 2014, s. 91). To właśnie do takiej rozmowy często zapraszają alternatywni artyści - tyle że w obrębie własnej kultury, a nie, jak robią to uczący języka - na skrzyżowaniu wielu kultur.

Czytelnik niniejszego artykułu ma prawo uznać, że prowadzone rozważania o roli muzyki alternatywnej kreują zbyt jednostronny obraz uczących się - jako obytych $\mathrm{z}$ własną i globalną kulturą, otwartych na nowe bodźce kulturowe. I rzeczywiście, w pracy z tekstami powstającymi w kontrze do zastanego stanu kultury znajomość kodów i biegłość w poruszaniu się wśród kultury popularnej, nabytych uprzednio we własnej kulturze, będą stanowiły duże ułatwienie. Piotr Kajak, zdeklarowany akafan ${ }^{2}$, pisze o fenomenie hip-hopu i fenomenie sztuki ulicy, które, dzięki znajomości globalnych nawiązań, ułatwiają studentom zrozumienie lokalnych kontekstów. Przykład hip-hopu pokazuje, że znajomość wyznaczników gatunku odgrywa ważną funkcję komunikacyjną. Czy nie jest uprawnione wyciągnięcie wniosków, że refleksja o hip-hopie jako „swoistym lingua franca” (Kajak 2019, s. 250) może zostać poszerzona na inne gatunki, które zostaną trafnie rozpoznane przez uczestników procesu komunikacyjnego? Jeśli w swoim kraju ktoś jest fanem np. elektro-popu, tematy poruszane przez zespoły z innego kręgu

${ }^{2}$ Zbitka wyrazów akademik i fan (ang.: aca-fan, acafan), używana do określenia postawy, która łączy krytyczne spojrzenie, typowe dla badań akademickich z zaangażowaniem sympatyka (fana). Termin pojawił się w dyskusji akademickiej nad kulturą fanów w początkach lat 90 . Za popularyzację terminu odpowiadają M. Hills (2002) oraz H. Jenkins (2020). Na polu glottodydaktyki polonistycznej termin wprowadzony przez Piotra Kajaka (por. Kajak 2020, s. 156). 
kulturowego, a także wykorzystane przez nie środki językowe (sposób obrazowania) nie będą dla niego całkowitym zaskoczeniem. Oczywiście wypada przyznać hip-hopowi rolę szczególną, co najmniej z dwóch względów. Po pierwsze, ze względu na popularność gatunku, jego globalny charakter, przy jednoczesnym zachowaniu lokalnej różnorodności. Po drugie dlatego, że w hip-hopie to właśnie język pełni szczególną rolę, gdyż sam w sobie jest najważniejszym tworzywem³ Gdy dla jednych wspólnym punktem odniesienia będzie hip-hop, dla innych może to być choćby techno, ale jeśli zdołamy stworzyć odpowiednie warunki do komunikacji na płaszczyźnie gatunków, z włączeniem polskiej muzyki, jako nagrodę zyskamy możliwość obserwacji, jak dzięki porozumieniu wokół muzyki, tworzą się zaczątki „nowej kultury”: „Claire Kramsch (1993) określiła tę nabudowaną część tożsamości uczących się trzecia kultura, natomiast polski badacz komunikacji międzykulturowej, Jerzy Nikitorowicz (1995), mówi o kulturze pograni$c z a$ - nowej tożsamości powstającej w wyniku dialogu kulturowego" (Zarzycka 2008, s. 69).

\section{O PRZYDATNOŚCI KATEGORII MUZYKA ALTERNATYWNA}

Dlaczego muzyka alternatywa, a nie pop czy rock z list przebojów, rocznych czy bezwzględnych podsumowań lub innych rankingów, które pozwalają mierzyć popularność i na tej podstawie dowiedzieć się, czego słuchają Polacy? Odpowiedź brzmi: one też są ważne! „Zawsze lubię starą popową muzykę, ponieważ myślę, że stara muzyka, która jest popularna obecnie, jest prawdziwym symbolem kultury" - stwierdziła jedna ze studentek, zapytana o to, z jakiego typu piosenkami chciałaby pracować na zajęciach. Decyzja o wyborze materiałów dydaktycznych należy do lektora, ale jeżeli chodzi o czas spędzony poza salą lekcyjną, to uczący się sami muszą dokonać indywidualnego wyboru, czego będą słuchać, a my możemy ich tylko wspierać. „Publikacja w sieci prywatnych playlist złożonych z ulubionych piosenek jest elementem autokreacji, odrębnym kanałem porozumienia. Playlista znaczy już poprzez samo zestawienie tytułów, sprowadza muzykę do znaku określającego indywidualność, do gestu własnego wyboru, będącego jednocześnie zaproszeniem do komunikacji” (Księżyk 2018, s. 20). Jeśli chcemy mieć udział w wypełnianiu tej playlisty utworami wartościowymi z naszej perspektywy, musimy wskazywać różne kierunki muzycznych poszukiwań.

${ }^{3}$ Wagę utworów hip-hopowych w refleksji nad językiem na tle innych polskich piosenek docenia też dziennikarz muzyczny B. Chaciński w zaproponowanym z okazji Międzynarodowego Dnia Języka zestawieniu Język polski w 10 piosenkach „(...) postanowiłem zebrać różne aspekty polszczyzny w aż 10 utworach muzycznych. Po to, żeby się po raz kolejny przekonać, jak bardzo polszczyzną interesuje się polski hip hop": https://polifonia.blog.polityka.pl/2018/02/21/jezyk-polski-w-10-piosenkach/ [publikacja 21.02.2018, dostęp 09.05.2020]. 
Myśląc o pracy z piosenką, należy myśleć nie tylko o realizacji celów dydaktycznych podczas konkretnej jednostki lekcyjnej, ale szerzej, o stymulowaniu do jak największej ekspozycji na język (por. Siek-Piskozub, Wach 2006, s. 46-48). W tym miejscu powołam się na badania R. Dębskiego (2015, s. 70) o roli procesu zastępowania „mediów przekazu” przez „media uczestniczenia” w kształceniu językowym. Dębski wykazuje, że zwiększenie udziału urządzeń elektronicznych i transmitujących w naszej rzeczywistości ma pozytywny wpływ dla zachowania czy odrodzenia języków rzadkich. Podobnie dzisiejsza wszechobecność urządzeń elektronicznych daje szansę na pomoc w nabywaniu nowego języka, choćby dzięki temu, że ułatwia włączenie ucznia, słuchacza czy studenta w krąg odbiorców polskiej muzyki. W nowoczesnej pedagogice, która powinna podążać w ślad za potrzebami i nawykami uczących się, jednym z naszych celów powinno być aktywizowanie studentów do tego, by ich osobiste playlisty wypełniała różnego rodzaju polska muzyka. To jeden z wielu środków, które mogą pomóc przekształcić uczących się w fanów polskiej kultury (por. np. Kajak 2020 s. 79).

Podsumowując, chociaż „muzyka alternatywna” nie wydaje się kategorią niezbędną, bez wątpienia jest niezwykle wartościowa. Po pierwsze, jeżeli chodzi o poszukiwanie tekstów stymulujących do porównywania kultur czy inicjowania dyskusji nt. polskiej kultury. Po drugie, jest wartościowa również dlatego, że pomaga zwiększać różnorodność propozycji muzycznych.

\section{SZERSZE SPOJRZENIE NA MIEJSCE PIOSENKI W NAUCZANIU JĘZYKA I KULTURY POLSKIEJ}

Funkcje muzyki (mowa nie tylko o piosenkach) w nauczaniu języków przedstawiono w książce Muzyka i słowa. Wyróżniono następujące funkcje: motywującą, integrującą, terapeutyczną, organizacyjną, dydaktyczną i poznawczą (Siek-Piskozub, Wach 2006, s. 111-116). Obszerniejsze badania na temat wykorzystania piosenek przeprowadziła też J. Deczewska, która doszła do wniosku, że: „Nauczyciele wykorzystujący piosenkę podkreślają jej walory zwłaszcza w zakresie zwiększenia motywacji do nauki oraz optymalizacji procesu nauczania" (2014, s. 135)4. Myśląc o wykorzystaniu piosenek, także na lekcjach kulturowych, warto pamiętać, że „nie zawsze uczący się musi dostrzegać założenia nauczyciela, dotyczące na przykład doskonalenia kompetencji gramatycznej" (Kaźmierczak 2019) - ten potencjał piosenek do uczenia gramatyki jakby przy

${ }^{4}$ Cytowana autorka nie jest polonistką, a jej szczegółowe badania dotyczą nauczania języka rosyjskiego. Obroniła ona rozprawę doktorską pt. Teksty śpiewane w nauczaniu języków obcych, dochodząc do wniosku, że ,piosenka stanowi pełnowartościowy środek optymalizacji nauczania języków obcych" (Deczewska 2015). 
okazji stanowi silny, odrębny argument za włączaniem ich do programów lektoratów. W dalszych rozważaniach pozostańmy jednak w kręgu refleksji nad nauczaniem kultury i przyjrzyjmy się obecności piosenki w programach i katalogach tematycznych, które służą przede wszystkim nauczaniu kultury (lub języka, $\mathrm{z}$ rozwinięciem kontekstu kulturowego). W jakich kontekstach pojawiają się piosenki w refleksjach badaczy i czy możemy odnaleźć tam przykłady z kręgu tzw. muzyki alternatywnej?

$\mathrm{Na}$ początku przyjrzę się dwóm propozycjom porządkującym. Pierwsza to próba sklasyfikowania skrzydlatych słów (będących częścią rodzimej lingwakultury) w celu stworzenia programu ich nauczania (pełne zestawienie i opis metodologii: Zarzycka 2010, s. 121-142; samo pojęcie „lingwakultura”: Zarzycka 2000, Zarzycka 2004). W przywoływanym zestawieniu cytaty z piosenek pojawiają się najczęściej w kategorii „Dewizy życiowe, maksymy filozoficzne i pseudofilozoficzne”. To aż 11 z 30 pozycji zamieszczonych w tej kategorii: „Chcemy być sobą”, „Chłop żywemu nie przepuści”, „Chłopaki nie płaczą”, „Do tanga trzeba dwojga”, „Dobrze być cysarzem”, „Dziwny jest ten świat”, „Ja tu tylko sprzątam”, „Jestem z miasta, to widać, słychać i czuć”, „Miłość ci wszystko wybaczy”, „Nie o to chodzi, by złowić króliczka...”, „Piosenka jest dobra na wszystko” (pełna lista, wraz z autorami i wykonawcami oraz propozycją poziomu nauczania - Zarzycka 2010, s; 129-130). Osobne miejsce w zestawieniu analizowanym przez Zarzycką zajmuje Kazik Staszewski, przywołany dwukrotnie jako przykład, na podstawie którego można wyjaśniać studentom wyższych poziomów polskie wulgaryzmy i potocyzmy (Coście skurwysyny, uczynili z ta krainą?, Jeszcze Polska i Wałęsa, dawaj moje sto milionów!). Piosenki spotkamy też w innych kategoriach, np. „Apele/wezwania”, „Pytania”. Na podstawie przywoływanej analizy skrzydlatych słów można odnieść wrażenie, że te pochodzące z piosenek są bogatym źródłem zasilającym polską , lingwakulturę głównego nurtu” (Zarzycka 2004). Jasno zarysowane kategorie są nieocenioną pomocą $w$ pracy $z$ tekstami kultury popularnej, $w$ tym z muzyką alternatywną, bowiem pomagają nawigować pośród obfitości i wybierać to, co wartościowe i użyteczne. „Wydaje się, że w glottodydaktyce kanon kultury jest raczej bazą danych. Ogrom materiału i różnorodność studentów oraz różnorodność tożsamościowa Polaków powodują, że bardziej sprawdza się kanon rozumiany jako baza danych, w jakiś sposób porządkująca różne, «rozproszone» kanony" (Kajak 2010, s. 62). Skoro mamy do czynienia z bazą danych - będącą opozycją wobec konsekwentnej, uporządkowanej narracji („Baza danych i narracja są zatem naturalnymi wrogami” - pisze przywoływany przez Kajaka Lev Manovich), to rośnie znaczenie kategoryzacji i selekcji. Wobec braku możliwości oparcia pracy z kulturą popularną na jednorodnym kanonie, wobec natłoku możliwości i przy ryzyku zbytniego kierowania się własnym gustem - takie ramy wytyczone przez badaczy powinny stanowić podstawę lektorskiej refleksji podczas dobierania materiału z zakresu kultury popularnej. 
Drugie zestawienie wskazuje miejsce piosenki wśród fenomenów polskiej kultury. Znajdziemy je w pracy G. Rudzińskiego (Rudziński 2010). Nawet jeśli propozycja nie odzwierciedlałaby kulturowych aspiracji „typowego Polaka” (który, jak wiadomo, nie istnieje), to jest interesująca, bo reprezentuje preferencje adeptów naszej profesji. Poniżej wymieniam tylko te fenomeny, które są związane (bezpośrednio lub pośrednio) z muzyką.

- Postaci: Marek Grechuta, Maryla Rodowicz, Maria Peszek, Tomasz Stańko, Marek Kondrat ${ }^{5}$

- 42 fenomeny wskazywane przez badanych pojedynczo: dzieła muzyczne Krzysztofa Pendereckiego, hip-hop i jego wpływ na kulturę, Kabaret Starszych Panów, kaszubska piosenka z obrazkami (tzw. „Kaszubskie nuty”, „Kaszëbsczé Nótë”), muzyka Chopina, przystanek Woodstock, zespół Mazowsze;

- 16 najczęściej wskazywanych fenomenów: muzyka rockowa lat 80., Wielka Orkiestra Świątecznej Pomocy (Rudziński 2010).

Wyodrębnienie muzyki lat 80. jako fenomenu kulturowego jest niezwykle istotne dla refleksji nad muzyką alternatywną, bowiem jest to czas kształtowania się zjawisk, do których wciąż odwołują się współcześni artyści alternatywni. Mówiąc w dużym skrócie, to wtedy piosenki zespołów funkcjonujących „w szarej strefie" (M. Pęczak) zaczęły przejawiać ambicję do komentowania rzeczywistości.

W kolejnym kroku chciałbym zwrócić uwagę na studium przypadku (Roter-Bourkane 2012). Autorka selekcję materiału piosenkowego i działania dydaktyczne w konkretnej sytuacji motywuje zdziwieniem uczących się (zdziwienie jako warunek pedagogiki opartej na kulturze popularnej - por. cytowany tekst Z. Melosika 2014). „Pomysł na (...) opracowanie metodyczne zawdzięczam moim studentom, których zaintrygowały rozklejone na mieście plakaty kobiety w pióropuszu (grupa początkująca) i medialny szum wywołany «obscenicznością» materiału (grupa zaawansowana)" (Roter-Bourkane 2012, s. 140). Taka postawa lektorska to doskonała reakcja na zgłoszone przez samych studentów potrzeby, bo pomaga rozwijać „ciekawość innych i ich świata” (to jeden z warunków skutecznej komunikacji: „bez niej nie narodzi się interkulturowy rozmówca”, por. Zarzycka 2018, s. 539).

Powyższa propozycja zajęć na podstawie utworów Marii Peszek potwierdza, że piosenki (zwłaszcza te, wyrażające ciekawość lub zgłaszające wątpliwości

${ }^{5}$ Może Kondrat w pierwszej chwili nie jest kojarzony jako wokalista, ale pozwolę sobie przypomnieć Mydełko FA, często tak błędnie przywoływane przez Polaków jako utwór z kręgu disco polo. Pisze o tym m.in. Monika Borys: „Pastisz disco polo w wykonaniu artystów wymknął się spod kontroli. Zamysł prześmiewczy został przez publiczność niezrozumiany albo zignorowany; zapewne również skala popularności przerosła oczekiwania twórców. Piosenka, mimo wstępnych założeń, weszła do kanonu gatunku" (https://www.dwutygodnik.com/artykul/8392-mydelko-fa. html [25.04.2020]). Swoją drogą, to niezwykle interesujące (np. w kontekście zadawanych często przez uczących się pytań), że wśród wyróżnionych tu fenomenów polskiej kultury nie pojawiło się disco polo. 
wobec własnej kultury, a więc otwierające na dyskurs) są odpowiednim narzędziem do wykorzystania w nauczaniu interkulturowym. Mogą być bodźcem do aranżowania podczas zajęć sytuacji odpowiednich do pogłębiania ciekawości innych i świata (,warunek narodzenia się interkulturowego rozmówcy”), spotkania („mojego świata ze światem innych”), porównywania, zestawiania wzorców odmiennej kultury ze wzorcami własnej (por. Zarzycka 2018, zestawienie słów kluczy, charakteryzujących pedagogikę międzykulturową).

\section{PRZYKLADY}

Poniżej przywołuję kilka utworów z kręgów muzyki alternatywnej, które z powodzeniem mogą posłużyć przygotowaniu zajęć kulturowych. Listę uzupełniam krótkimi notatkami na temat ich potencjalnego zastosowania. Jest to subiektywny wybór dokonany na podstawie materiałów własnych autora, a każda z lekcji została przeprowadzona co najmniej trzykrotnie. Do odczytania sensów zawartych we wskazanych tekstach nie wystarczy słownik i zrozumienie leksyki. Potrzebna będzie pomoc ,interkulturowego rozmówcy” (Kramsch 1998, za: Zarzycka 2008). Utwory umieszczam w ramach kategorii omówionych na polu kulturoznawstwa glottodydaktycznego, a dokładniej, próbuję zbadać ich adekwatność z propozycjami programowymi z tomu Kultura w nauczaniu języka polskiego jako obcego (2009). Ze względu na jego postulatywny charakter, odwołuję się do rozdziału Jak być powinno (omówienie koncepcji programowych przedstawionych w tomie i opis ich znaczenia dla nauczania KPJO, zob. Kajak 2020, s. 116-119).

Próbując przyporządkować przywoływane teksty zgodnie z propozycją programową Burzyńskiej i Dobesz (2009, s. 119-128), właściwie każdy z utworów można by rozpatrywać w ramach nadrzędnych kategorii Człowiek. Tradycja (inwentarz tematyczny) lub Role społeczne i typy kontaktu (inwentarz funkcjonalno-pojęciowy). Większą szczegółowość zauważymy, zestawiając piosenki z kategoriami zaproponowanymi przez P. Gębala (2009, s. 129-147). Jak zauważa Kajak (2020, s. 119): „Badacz promuje optykę eklektyczną (eklektyczne ujęcie realioznawstwa), łączące podejście kognitywne (faktograficzne - prezentujące obraz kraju), komunikacyjne (skupiające się na kulturze życia codziennego) i międzykulturowe (umożliwiające próbę zrozumienia kultury własnej i obcej)".

\section{Przykładowe piosenki}

1. „Dzisiaj jeszcze tańczę, dzisiaj jeszcze śpiewam, ale jutro to się skończy, rano będzie trzeba wstać, będzie trzeba iść do pracy...”, „Ach, jak trudno walić młotem, kiedy wszyscy dookoła patrzą ci na ręce”. Wczasy, Dzisiaj jeszcze tańczę... 
- Czy tylko Polacy nie lubią poniedziałku? Piosenka w ciekawy sposób może otwierać studentów na rozmowę o pracy i jej roli w różnych kulturach. Np. podczas zajęć z grupą chińską wywiązała się interesująca i pogłębiona rozmowa o obawach studentów związanych z pracą w modelu 9/9/6 .

- Rekomendowany poziom - od B1.

Gębal: Relacje międzyludzkie, Praca, Wolny czas ${ }^{7}$

2. „Czuję się jak król, sprzedawca to mój paź...”. Wczasy, Świętokracja

- To nietypowa propozycja świąteczna. Tekst piosenki porusza problem konsumpcji, stosunku do tradycji. To tematy istotne z punktu widzenia wielu kultur - rekomendowany poziom od B1, przy pracy z wybranymi fragmentami tekstów.

- Król, paź, berło, korona - w tekście ujawnia się zakodowany w języku polskim i w naszej świadomości obraz hierarchii społecznej, ukształtowany historycznie, co można wykorzystać w pracy na wyższych poziomach biegłości językowej.

Gębal: Relacje międzyludzkie, Zwyczaje i obyczaje, Zakupy i usługi, Normy i systemy wartości

3. „Na niebie ptaki dają radę bez ojczyzn i bez banków, a na nas przecież nawet włosy wszystkie policzone”, „Polećmy w nową przestrzeń, bez zaciśniętych pięści...". Pogodno, Tak, to teraz

- Czy wszystko musimy mieć pod kontrolą? Czy w polskiej kulturze możemy popełniać błędy, zmieniać zdanie? Co to znaczy zaczynać od nowa i kto może sobie na to pozwolić?

- Kiedy musimy zacisnąć pięści, a kiedy możemy wziąć głęboki oddech? $\mathrm{Na}$ ile ważne w poszczególnych kulturach jest realizowanie narzuconego odgórnie schematu postępowania?

- Piosenkę można wykorzystać jako punkt wyjścia do prezentacji czy rozmowy o tym, jak możemy obrazować w języku polskim wyrażanie emocji.

- Rekomendowany poziom - od B1.

Gębal: Tożsamość osobista, Język ciała w relacjach międzyludzkich

4. „Za 500 dostajesz maskotkę, bynajmniej dla mnie są one mega słodkie...”. Mister D. ${ }^{8}$, Chleb

${ }^{6}$ Chodzi o kontrowersje wokół wypowiedzi Jacka Ma z kwietnia 2019 nt. pracy w godzinach nadliczbowych, więcej np. tu: https://tvn24.pl/biznes/ze-swiata/jack-ma-o-modelu-996-taka-praca -to-blogoslawienstwo-ra927188-4506428 [06.05.2020].

${ }^{7}$ Każdorazowo wskazuję na kategorie klasyfikacyjne z inwentarza P. Gębala (2009).

${ }^{8}$ Mister D. to projekt Doroty Masłowskiej i w gruncie rzeczy trudno sklasyfikować tę piosenkę jako reprezentującą muzykę alternatywną - co dowodzi płynności granic. Obserwujemy tu jeszcze inny sposób zaistnienia utworu, wynikający zapewne z popularności uczestniczek projektu na in- 
- Język polski czy języki polskie...? Tekst tej piosenki wydaje się bardzo złożony, a jednak dość łatwo możemy uczynić go bardziej przystępnym dla studentów. Dużym ułatwieniem jest wskazówka, że piosenkę należy czytać, przełączając się między różnymi kodami języka polskiego: językiem reklamy, językiem potocznym, zawierającym częste błędy i językiem niezbyt wyszukanej metafory poetyckiej (osadzonej w paradygmacie poezji romantycznej, dominującym w polskim popie). Próba oddzielenia tych partii tekstu może być jednym z ćwiczeń wprowadzających. Dzięki takiej wskazówce można pracować z tekstem już nawet od poziomu B2.

- Pole semantyczne wokół pojęcia 'chleb'.

- Stosunek do rodziców.

- Dodatkowym atutem jest wideoklip z udziałem Anji Rubik, modelki często rozpoznawanej przez zagranicznych studentów.

Gębal: Rodzina, Państwo („My” i „Oni”, margines społeczny itp.), Relacje międzyludzkie, Normy i systemy wartości

5. „Mój własny zięć nie chce jeść polskich mięs”, „Mój własny wnuk ubrał się w róż”, „Jej własny mąż sam sprząta dom”. Ryby, Polska.

- Płeć a rola społeczna. Tekst piosenki zawiera wiele bodźców do dyskusji na temat obowiązujących i zmieniających się wzorców kulturowych.

- Rytmika i akordy tej piosenki kojarzą się nieco z Been a son Nirvany (w której poruszony został problem stereotypowego postrzegania płci i tradycyjnego pragnienia posiadania syna przez konserwatywnych mężczyzn). Skojarzenie może być dostępne wielu fanom rocka.

- Rekomendowany poziom - minimum B2.

Gębal: Tożsamość osobista, Państwo, Zwyczaje i obyczaje

Podsumowując, w kulturoznawstwie glottodydaktycznym przydatne mogą być szczególnie takie piosenki z kręgu muzyki alternatywnej, które posiadają jedną lub więcej z poniższych cech:

- mają charakter dyskursywny w stosunku do wzorców zachowań powielanych w kulturach, tak lokalnych, jak i zglobalizowanych, dzięki czemu mogą wprowadzać $\mathrm{w}$ atmosferę dialogu,

- w sposób nowatorski podchodzą do wykorzystania języka,

- zawierają frazeologizmy lub inne miejsca w tekście o charakterze lingwakulturowym, „bogate pod względem znaczeniowych punktów” (por. Zarzycka 2004, s. 435-444).

Dzięki piosenkom możemy pomagać uczącym się w stawaniu się coraz lepszymi ekspertami w zakresie realioznawstwa, krajoznawstwa, socjoznawstwa czy

nych polach. To zdecydowanie najczęściej odsłuchiwany w Internecie utwór pośród wymienionych propozycji (prawie $9 \mathrm{mln}$ w porównaniu do maksymalnie kilkuset tysięcy - stan na 14.05.2020). 
kulturoznawstwa sensu stricto (Pffeifer 2001, s. 157-159). Niewątpliwym ułatwieniem będzie umiejętność przyporządkowania przez nich utworów do któregoś ze stylów lub „międzystylów” zidentyfikowanych uprzednio we własnej kulturze i możliwość odnalezienia nowej wartości estetycznej na tle rozpoznawanej konwencji. Wybór spośród możliwości oferowanych w „hipermarkecie kultury” (John Fiske, więcej: np. Kajak, 2020, s. 75) pozostanie indywidualną decyzją lektora, wynikającą z potrzeb i zainteresowań grupy. Tak jak nie ma uniwersalnego kanonu tekstów kultury popularnej, tak nie ma jednego katalogu piosenek z kręgu muzyki alternatywnej. Możliwe do wyobrażenia są natomiast rozmaite katalogi tematyczne lub propozycje programowe, włączające je w proces nauczania.

\section{BIBLIOGRAFIA}

Burzyńska A.B., Dobesz U., 2009, Program nauczania cudzoziemców realiów polskich, w: W. Miodunka (red.), Kultura w nauczaniu języka polskiego jako obcego, Kraków, s. 119-128.

„Czas Kultury” 2001, nr 1(100).

Deczewska J., 2014, Dobór repertuaru kluczem do sukcesu w pracy z piosenka na zajęciach językowych, „Języki Obce w Szkole” nr 4, s. 135-138.

Deczewska J., 2015, Teksty śpiewane w nauczaniu języków obcych, rozprawa doktorska przygotowana pod kierunkiem prof. Ludmiły Szypielewicz, Uniwersytet Warszawski, Wydział Lingwistyki Stosowanej.

Dębski R., 2015, Wpływ nowych technologii na dynamikę utrzymania języka polskiego w świecie. W poszukiwaniu modelu badawczego, „Poradnik Językowy”, nr 8, s. 61-72.

Garncarek P., 2012, Dlaczego kultura popularna nie ma czasu, w: P. Garncarek, P. Kajak (red.), Kultura popularna w nauczaniu języka polskiego jako obcego, Warszawa, s. 11-17.

Gębal P., 2009, Program nauczania cudzoziemców realiów polskich, w: W. Miodunka (red.), Kultura w nauczaniu języka polskiego jako obcego, Kraków, s. 129-147.

Hills M., 2002, Fan cultures, London.

https://polifonia.blog.polityka.pl/2018/02/21/jezyk-polski-w-10-piosenkach/ [09.05.2020].

https://tvn24.pl/biznes/ze-swiata/jack-ma-o-modelu-996-taka-praca-to-blogoslawienstwo -ra927188-4506428 [06.05.2020]

https://www.dwutygodnik.com/artykul/8392-mydelko-fa.html [25.04.2020]

Jenkins H., 2020, Confessions of an aca-fan, www.henryjenkins.org, [18.05.2020].

Kajak P., 2010, Nauczanie kultury polskiej w epoce globalnych treści kulturowych, w: P. Garncarek, P. Kajak, A. Zieniewicz (red.), Kanon kultury w nauczaniu języka polskiego jako obcego, Warszawa, s. 53-64.

Kajak P., 2019, Gloire à l'art de rue - o hiphopologii polonistycznej stów kilka, w: M. Ivanová, A. Kobylińska, P. Pająk (red.), Stowacja, Europa Środkowa i jeszcze dalej. Tom dedykowany Profesor Joannie Goszczyńskiej, Warszawa, s. 247-257.

Kajak P., 2020, Kultura popularna w nauczaniu polszczyzny jako języka obcego. Wstep do kulturoznawstwa glottodydaktycznego, Warszawa. https://doi.org/10.31338/uw.9788323541264

Kaźmierczak P., 2019, Piosenka pomoże na wiele, czyli o alternatywnych sposobach kształtowania kompetencji gramatycznej, „Acta Universitatis Lodziensis. Kształcenie Polonistyczne Cudzoziemców", t. 25, B. Grochala, I. Dembowska-Wosik (red.), s. 137-148. https://doi. org/10.18778/0860-6587.25.12 
Kołak-Danyi K., 2019, Made in Poland. Polskie zjawiska kulturowe jako bariery i pomosty w nauczaniu JPJO, „Język a Edukacja”, t. 7, s. 131-140.

Kramsch C., 1993, Context and culture in language teaching, Oxford.

Kramsch C., 1998, Language and culture, Oxford.

Księżyk R., 2018, Wywracanie kultury. O dandysach, hipsterach i mutantach, Wołowiec, s. 19-20.

Melosik Z., 2014, Kultura popularna jako czynnik socjalizacji, w: Z. Kwieciński, B. Śliwerski (red.), Pedagogika: podręcznik akademicki 2, Warszawa, s. 85-91.

Miodunka W. (red.), 2009, Kultura w nauczaniu języka polskiego jako obcego, Kraków.

Nikitorowicz J., 1995, Pogranicze. Tożsamość. Edukacja międzykulturowa, Białystok.

Pęczak M., 2018, Muzyka jako wehikut ,ideologii” subkulturowej w czasach PRL, w: M. Jeziński, M. Pranke, P. Tański (red.), Głowa mówi. Polski rock lat. 80., Toruń, s. 43-63, http://meakultura.pl/cdn/files/glowa-mowi-polski-rock-lat-80.pdf, [04.05.2020].

Pffeifer W., 2001, Nauka języków obcych. Od praktyki do praktyki, Poznań.

Raport o stanie polskiej muzyki, 2011, Warszawa, https://imit.org.pl/uploads/files/raport-o-stanie -muzyki/Raport-IMIT_2011.pdf, [09.05.2020].

Rerak S., 2013, Chtepcac ciekty hel - Historia yassu. Gdynia.

Roter-Bourkane A., 2012, „Ładne słowa to...” - jak bawić się językiem, stuchając Marii Awarii, w: P. Garncarek, P. Kajak (red.), Kultura popularna w nauczaniu języka polskiego jako obcego, Warszawa, s. 139-146.

Rudziński G., 2010, Ranking fenomenów polskiej kultury autorstwa studentów specjalizacji nauczania języka polskiego jako obcego, w: P. Garncarek, P. Kajak, A. Zieniewicz (red.), Kanon kultury w nauczaniu języka polskiego jako obcego, Warszawa, s. 207-214.

Siek-Piskozub T., Wach A., 2006, Muzyka i słowa. Rola piosenki w przyswajaniu języka obcego, Poznań.

www.sjp.pwn.pl [04.05.2020]

Zarzycka G., 2004, Linguakultura - czym jest, jak ją badać i „otwierać”?, w: A. Dąbrowska (red.), Wroctawska dyskusja o języku polskim jako obcym, Materiały z Międzynarodowej Konferencji Stowarzyszenia ,Bristol”, Wrocław, s. 435-444.

Zarzycka G., 2008, Opis pedagogiki zorientowanej na rozwój kompetencji i wrażliwości interkulturowej, w: W. Miodunka, A. Seretny (red.), W poszukiwaniu nowych rozwiazań: dydaktyka języka polskiego jako obcego u progu XXI wieku, Kraków, s. 63-77.

Zarzycka G., 2010, Skrzydlate słowa w procesie nauczania języka polskiego jako obcego. Propozycje programowe, w: P. Garncarek, P. Kajak, A. Zieniewicz (red.), Kanon kultury w nauczaniu języka polskiego jako obcego, Warszawa, s. 121-142.

Zarzycka G., 2018, Podejście interkulturowe w nauczaniu języka polskiego jako obcego. Bilans i perspektywy, w: W kręgu glottodydaktyki, t. 5, Katowice 2018, s. 534-548.

\section{Piosenki wymienione w części 5., dostęp online}

Mister D., Chleb, muz., słowa: Dorota Masłowska, album Społeczeństwo jest niemiłe, Raster, 2014 https://www.youtube.com/watch?v=-1-z48cJDbc, [14.05.2020].

Pogodno, Tak, to teraz, muz., słowa: Pogodno, album Sokiści chca miłości, Mystic Production, 2017 https://www.youtube.com/watch?v=jGpP0zSA8Ko, [14.05.2020].

Ryby, Polska, muz: J. Małkowski, G. Uzdański i Ryby, słowa: G. Uzdański https://www.youtube. $\mathrm{com} /$ watch?v=lbDrJO5fQxo, [14.05.2020].

Wczasy, Dzisiaj jeszcze tańczę, muz., słowa: Bartłomiej Maczaluk i Jakub Żwirełło, album Zawody, Thin Man Records, 2018, https:/www.youtube.com/watch?v=zhcEINkncnQ, [14.05.2020].

Wczasy, Świętokracja, muz., słowa: Bartłomiej Maczaluk i Jakub Żwirełło, album Przeżyj święta (różni artyści), Na Siano Records, 2017, https://www.youtube.com/watch?v=p_mPUaWqUq8, [14.05.2020]. 
Tomasz Wegner

\section{ALTERNATIVE MUSIC AS A STIMULUS FOR INTERCULTURAL DIALOGUE}

Keywords: alternative music, indie music, the role of songs in teaching of Polish language and culture, linguacultural representation in the songs

Abstract. The article contains reflection about usefulness of the songs classified as alternative/ indie music for didactics of Polish language and culture. The author proves that numerous songs from this group contain rich representation of Polish linguaculture as well as present discursive attitude towards the cultural references. Both features make alternative/indie music a valuable source for searching of the lyrics which can give an impulse to compare cultures, seek understanding within different cultures as well as initiate discussion on Polish culture. The theoretical background for the article is set by the discussion taking place among Polish glottodidactics researchers for the last 20 years. In the final part of the article author refers to a few examples of songs used in his own teaching practice. The author compares his subjective selection of the titles with teaching programs in Polish culture for foreigners. 